\title{
Cadmium Concentrations in Recent Snow and Firn Layers in the Canadian Arctic
}

\author{
J. O. Nriagu, ${ }^{\star}$ G. S. Lawson, D. J. Gregor
}

Environment Canada, National Water Research Institute, Box 5050, Burlington, Ontario L7R 4A6, Canada

\section{Received: 21 July 1993/Accepted: 30 November 1993}

It is becoming increasingly evident that long-range transported pollutants can have a devastating effect on the fragile ecosystems of the Canadian Arctic region (Muir et al., 1992; Thomas et al., 1992). The phenomenon of Arctic haze which prevails during the late winter-early spring period results in the flux of elevated quantities of toxic pollutants to the region (Nriagu et al., 1991; Landsberger et al., 1992). Although there have been studies of the atmospheric concentrations of pollutants in the region (Gregor, 1991; Barrie et al., 1992), there are no reliable measurements of the accumulation of trace metals in the snow and ice layers. Analysis of dated snow and ice layers in Greenland has furnished a wealth of information on the history of global air pollution with toxic metals (Wolff and Peel, 1988). Similar studies in Arctic Canada should provide additional insights into the hemispheric transport processes and the sources of trace metals in this polar region. This report presents the first set of data on the concentrations of cadmium in recent snow layers (deposited during the past 7 years) of the Agassiz Ice Cap, Ellesmere Island, Canada. The data were obtained using an ultra-clean sampling and analysis procedures.

\section{MATERIALS AND METHODS}

The Agassiz Ice Cap is located in north-central Ellesmere Island, Northwest Territories, Canada. The sampling site was approximately $1800 \mathrm{~m}$ above sea level. Features that dictated the choice of this site included: (a) snow accumulation represents about $75 \%$ of the average annual precipitation; (b) summer melting affects only $3 \%$ of the winter snow layer so that the redistribution of material between adjacent snow layers is negligible; (c) individual annual conductivity profiles are preserved in the historical records implying that the blurring of seasonal stratification by snow drift and seasonal melt is minimal (see Barrie et al., 1985; Gregor, 1991).

The sample pit was located upwind and approximately $1.7 \mathrm{Km} \mathrm{NW}$ from the base camp $\left(80^{\circ} 40^{\prime} \mathrm{N} 73^{\circ} 30^{\prime} \mathrm{W}\right)$. The pit, about one square meter, was dug in full cleanroom coveralls using a stainless steel shovel with a fibreglass handle. The digging was accomplished over two days (2-3 hrs/day). Any snow removed was discarded downwind away from the pit. All sampling equipment, except the

*Present address: Department of Environmental \& Industrial Health, School of Public Health, University of Michigan, Ann Arbor, MI 48109

Correspondence to: $\mathrm{J}$. O. Nriagu 


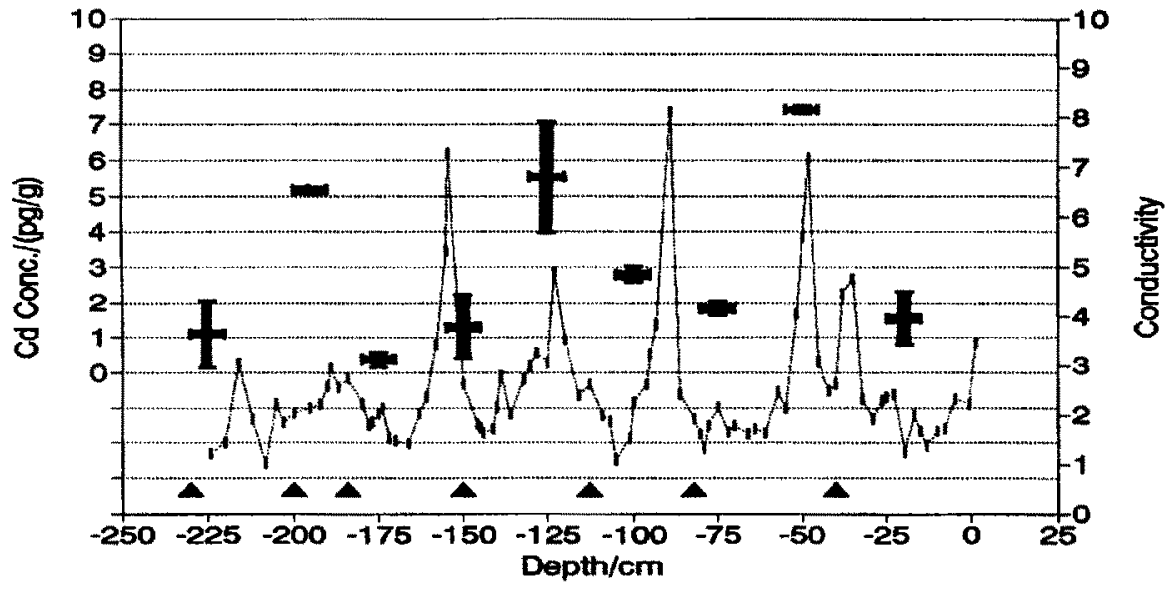

-+- Conductivity $\quad$ Summer lce Layer $\mathrm{Lm}$ Cd

Figure 1. Conductivity and cadmium concentrations in the snow and firn layers deposited during the past 7 years at the Agassiz lce Cap.Figure 1.

shovel, consisted of plastics which were acid-leached. Sampling down the side of the pit was accomplished using a Teflon coring tube. The tube corer was pressed into a freshly scraped surface (using a Teflon scraper). The sample was broken up in the corer by squeezing its sides and the sample was then poured into low density linear polyethylene (LDPE) $1 \mathrm{~L}$ wide-mouth bottles. The samples were double bagged then returned to the laboratory for acidification to $\mathrm{pH} 3$ or $\mathrm{pH} 1.5$ and analysis. All plastic equipment, including corer bottles, scrapers, and sample bottles were rigorously cleaned in successive acid baths as described previously (Nriagu et al., 1993).

All the sample handling and analysis were done in a Class 100 laboratory dedicated to research on trace metals. The cadmium content of each sample was determined by multiple injection of $10 \times 30 \mathrm{uL}$ samples into a graphite furnace AA instrument with Zeeman background correction (Wolff and Peel, 1988; Gorlach and Boutron, 1989). Simple field blanks, in triplicate, were obtained to determine possible changes in samples due to transport and storage. The measurements were below the detection limit of the instrumental technique for $\mathrm{Cd}$ (approx. $0.3 \mathrm{pg} / \mathrm{g}$ ). Sampling blanks for the coring procedure were not obtained so that blank correction due to procedural contamination has not been applied to the data being presented here. Replicates, however, were taken to test the variability between samples. These are shown as vertical error bars in Figure 1. The horizontal error bars in the figures represent the diameter of the coring bottles (10 $\mathrm{cm}$ ) since the concentrations are in fact mean values for the $10 \mathrm{~cm}$ time periods. 


\section{RESULTS AND DISCUSSION}

Barrie et al (1985) observed a strong seasonality in the conductivity and acidity in the snow layers at the Agassiz ice cap, which was closely correlated with seasonal fluctuations in air pollution in the region. Peaks in the conductivity and acidity values during the "Arctic winter" (late winter-early spring) were attributed to the deposition of pollutants in the Arctic haze. Strong seasonal fluctuations in conductivity are also observed in this study and have, in fact, been used to date the samples (Figure 1). Although there are marked differences in the year-to-year peak values, the conductivity during the off-peak periods remains low and shows no definitive trend during the last seven years.

Since continuous whole-year samples were not analyzed, it is impossible to define the detailed profile of cadmium concentration down the snow layers (Figure 1). Nevertheless, the $\mathrm{Cd}$ concentrations do indicate seasonal variations with peak values during the late winter-early spring period (Figure 1). The $\mathrm{Cd}$ concentrations during the peak and off-peak periods average 6.1 and $1.2 \mathrm{ng} / \mathrm{kg}$ respectively; the difference between the background and peak $\mathrm{Cd}$ concentrations is nearly 6 -fold. Late winter-early spring maxima likewise have been found in the concentrations of airborne trace metals at various locations in Arctic Canada (Barrie and Hoff, 1985; Cheng et al., 1991). The record of Cd deposition preserved in the snow and ice layers thus seems consistent with the general features of atmospheric air pollution in the region.

We are not aware of any published data which show comparable seasonal variations in the $\mathrm{Cd}$ content of recently deposited snow layers in the Arctic polar region. Wolff and Peel (1988) could not find any seasonal difference in the Cd concentrations in the snow layers of southern Greenland. The off-peak (background) Cd levels at Agassiz are similar to the $1.11 .6 \mathrm{ng} / \mathrm{kg}$ in surface snow samples collected in May 1987 at the Summit Station (elevation $\sim 3230 \mathrm{~m}$ ) in central Greenland (Gorlach and Boutron, 1989). The average annual $\mathrm{Cd}$ concentration in recent snow at the Dye 3 Station (elevation $\sim 2480 \mathrm{~m}$ ) in Greenland was found to be $0.74 \mathrm{ng} / \mathrm{kg}$ (Wolff and Peel, 1988). The higher Cd concentrations (2.6-6.0 ng/ $/ \mathrm{kg}$ ) in the accumulated snow in the GreenlandSpitsbergen region reported by Mart (1983) may be related to the fact that the sampling stations were at sea level. In view of the differences in elevation and location in relation to the sources of pollutants in the Arctic haze (Barrie et al., 1992), it is rather surprising that the Cd concentrations in deposited snow are similar in Greenland and the Ellesmere Island.

The average annual $\mathrm{Cd}$ concentration in recently deposited snow in the Antarctic Peninsula is only $0.07 \mathrm{ng} / \mathrm{kg}$ (Suttie and Wolff, 1991). By comparison with the data at our study site, it would appear that a large fraction of the background $\mathrm{Cd}$ burden in the Agassiz area is probably derived from anthropogenic sources. Data on other trace metals will be required to resolve the question of Canadian (local) versus transboundary sources of metal pollution at the Agassiz ice cap.

\section{REFERENCES}

Barrie, LA, Hoff, RM (1985) Five years of air chemistry observations in the Canadian Arctic. Atmos Environ 19: 1995-2010 
Barrie, LA, Fisher, D, Koerner, RM (1985) Twentieth century tends in Arctic air pollution revealed by conductivity and acidity observations in snow and ice in the Canaddian High Arctic. Atmos Environ 19: 2055-2063

Barrie, LA, Gregor, DJ, Hargrave, BT, Lake, R, Muir, D, Shearer, R, Tracey, B, Bidleman, T (1992) Arctic contaminants: sources, occurrence and pathways. Sci Total Environ 122: 1-74

Cheng, MD, Hopke, PK, Landsberger, S, Barrie, LA (1991) Distribution characteristics of trace elements and ionic species of aerosol collected in Canadian High Arctic. Atmos Environ 25A: 2903-2909

Gorlach, U, Boutron, CF (1989) Heavy metal concentrations in surface snow from central Greenland. In: Proc. Intl Conf Heavy Metal in the Environment (JP Vernet, Ed), CEP Consultants, Edinburgh, Vol. 1, pp. 24-27

Gregor, DJ (1991) Organic micropollutants in seasonal snowcover and firn. In: Seasonal Snowpacks (TO Davies et al., Eds), NATO ASI Series Vol. G28, Springer-Verlag, Berlin, pp. 323-357

Landsberger, S, Vermette, VG, Stuenkel, D, Hopke, PK, Cheng, MD, Barrie, LA (1992) Elemental source signatures of aerosols from the Canadian high Arctic. Environ Pollut 75: 181-187

Mart, $\mathrm{L}$ (1983) Seasonal variations of $\mathrm{Cd}, \mathrm{Pb}, \mathrm{Cu}$ and $\mathrm{Ni}$ levels in snow from the eastern Arctic Ocean. Tellus 35B: 131-141

Muir, DCG, Wagemann, R, Hargrave, BT, Thomas, DJ, Peakall, DB, Nordstrom, RJ (1992) Arctic marine ecosystem contamination. Sci Total Environ 122: $75-134$

Nriagu, JO, Coker, RD, Barrie, LA (1991) Origin of sulfur in Canadian Arctic haze from isotope measurements. Nature 349: 142-145

Nriagu, JO, Lawson, GS, Wong, HKT, Azcue, JM (1993) A protocol for minimizing contamination in the analysis of trace metals in the Great Lakes waters. J Great Lakes Res 19: 175-182

Suttie, ED, Wolff, EW (1991) Seasonal input of heavy metals to Antarctic snow. In: Proc. Intl Conf Heavy Metal in the Environment (JG Farmer, Ed), CEP Consultants, Edinburgh, Vol. 1, pp. 78-81

Thomas, DJ, Tracey, B, Marshall, H, Nordstrom, RJ (1992) Arctic terrestrial ecosystem contamination. Sci Total Environ 122: 135-164

Wolff, EW, Peel, DA (1988). Concentrations of cadmium, copper, lead and zinc in snow from near Dye 3 in south Greenland. Annals Glaciol 10: 193-197 